\title{
BOOK REVIEW: NGĀ TAI MATATŨ: TIDES OF MĀORI ENDURANCE
}

\author{
Tane Waetford*
}

Mason Durie Ngā Tai Matatū: Tides of Māori Endurance (Oxford University Press, Melbourne, 2005) (288 pages).

Māori have faced many challenges that have threatened their way of life and tested their ability to adapt to new and changing circumstances. Ngā Tai Matatū: Tides of Māori Endurance examines the many events that have shaped and influenced Māori life and analyses the way in which Māori have responded to such challenges. ${ }^{1}$ The analysis provides a valuable insight into Māori aspirations and values and provides a framework for future development. The book considers the way forward for Māori by looking at the position of Māori at the beginning of the third millennium and the challenges that lie ahead.

The author compares Māori progress with tidal patterns. It is common within Māoridom to use metaphors or parables in either written or oral communication, consistent with contextual learning. The metaphor in this instance is appropriate. Like the tides, progress has been uneven and inconsistent. $^{2}$ The comparison, however, also provides a sense of endurance. The book focuses on the enduring qualities of durability and resilience, which have ensured the survival of Māori culture and identity

Ngā Tai Matatū: Tides of Māori Endurance provides a carefully structured overview of Māori history, identifying some of the key challenges and events that have shaped Māori development. Perhaps the biggest challenge for the early Māori was the migration to Aotearoa. ${ }^{3}$ Their survival depended on the adaptability of tikanga (custom) and mana whenua (property rights). ${ }^{4}$ Large migration numbers necessitated rules of property and tenure, as well as the development of

\footnotetext{
Kaitakawaenga Māori, Faculty of Law, Victoria University of Wellington.

1 Mason Durie Ngā Tai Matatū: Tides of Māori Endurance (Oxford University Press, Melbourne, 2005).

2 Durie, above $\mathrm{n}$ 1, viii.

3 See Durie, above n 1, ch 1 .

4 Durie, above n $1,9$.
} 
relational customs between whānau, hapū, iwi, and inter-tribal relations. Adaptability and survival skills were further tested with the arrival of European trade and colonisation. Radical changes to the political and social scene led to such responses as the Kingitanga movement, Paremata Māori (Māori Parliament), Māori health initiatives, Māori educational institutions and political involvement. More recently, Māori have had to deal with issues such as urban transitions and globalisation.

The author presents comprehensive research and analysis throughout the book, drawing on published evidence. Chapter two, for example, looks at changing population trends and demographic patterns. ${ }^{5}$ The analysis provides an interesting look at how the population, composition and identity of Māori have evolved over the years. The Māori population in the twenty-first century is more numerous that at any other time. This expansion has brought with it greater challenges of diversity, cultural cohesion and homogeneity. The author however foresees outcomes such as improved health and higher levels of educational attainment as well as a fresh spirit of vitality, innovation, creativity and accomplishment. ${ }^{6}$

Ngā Tai Matatū: Tides of Māori Endurance considers many of the current issues that face Māori, and provides comprehensive research and analysis. ${ }^{7}$ It considers the way in which Māori have responded to previous challenges, and proposes a number of models and frameworks to deal with current and future challenges. ${ }^{8}$ As reflected in the title, Māori have demonstrated a durability and resilience that has ensured the survival of their culture and their identity. In the concluding chapter the author builds on this theme by proposing a framework for future development and growth. From the themes and case studies of Ngā Tai Matatū the author identifies four domains - te tai atua (spiritual), te tai tāngata (human), te tai tini (resource) and te tai ao (global). ${ }^{9}$ Future growth and success depends on the ability of Māori to find the right balance between these domains. Durie then employs a fifth domain - te tai hono (navigational). This domain provides the link between the various domains and recognises the challenges for leadership and longer-term planning.

5 See Durie, above n 1, 35, table 2.2.

6 Durie, above n 1,52 .

7 See for example Durie, above n 1, 136 "Scientific Research".

8 See for example Durie, above n 1, 148, fig 6.2.

9 Durie, above n 1, 236, table 10.1 . 